\title{
Disposal of children's stools and its association with childhood diarrhea in India
}

\author{
Rahul Bawankule ${ }^{1}$, Abhishek Singh ${ }^{2}$, Kaushalendra Kumar ${ }^{2 *}$ and Sarang Pedgaonkar ${ }^{3}$
}

\begin{abstract}
Background: Children's stool disposal is often overlooked in sanitation programs of any country. Unsafe disposal of children's stool makes children susceptible to many diseases that transmit through faecal-oral route. Therefore, the study aims to examine the magnitude of unsafe disposal of children's stools in India, the factors associated with it and finally its association with childhood diarrhea.

Methods: Data from the third round of the National Family Health Survey (NFHS-3) conducted in 2005-06 is used to carry out the analysis. The binary logistic regression model is used to examine the factors associated with unsafe disposal of children's stool. Binary logistic regression is also used to examine the association between unsafe disposal of children's stool and childhood diarrhea.

Result: Overall, stools of $79 \%$ of children in India were disposed of unsafely. The urban-rural gap in the unsafe disposal of children's stool was wide. Mother's illiteracy and lack of exposure to media, the age of the child, religion and caste/tribe of the household head, wealth index, access to toilet facility and urban-rural residence were statistically associated with unsafe disposal of stool. The odds of diarrhea in children whose stools were disposed of unsafely was estimated to be $11 \%$ higher $(95 \% \mathrm{Cl}: 1.01-1.21)$ than that of children whose stools were disposed of safely. An increase in the unsafe disposal of children's stool in the community also increased the risk of diarrhea in children.
\end{abstract}

Conclusion: We found significant statistical association between children's stool disposal and diarrhea. Therefore, gains in reduction of childhood diarrhea can be achieved in India through the complete elimination of unsafe disposal of children's stools. The sanitation programmes currently being run in India must also focus on safe disposal of children's stool.

Keywords: Children's stool disposal, Childhood diarrhea, India

\section{Background}

The disposal of children's stools has received little attention so far in the sanitation programmes of any country and, in fact, stools of young babies and children are regarded harmless and not dirty in many societies [1]. Interestingly, the sanitation programmes usually focus on household sanitation and overlook disposal practices of children's stool [2]. According to the World Health Organization (WHO), a child's stool is considered to be disposed of safely when the child uses the toilet/latrine; the faeces is put/rinsed in the toilet/latrine or buried. On the contrary, the disposal of stool is considered

\footnotetext{
* Correspondence: kaushalendrakumar1983@gmail.com

${ }^{2}$ Department of Public Health \& Mortality Studies, International Institute for

Population Sciences, Mumbai, India

Full list of author information is available at the end of the article
}

unsafe if the faeces is put/rinsed in a drain/ditch, thrown in the garbage, left or buried in the open [3]. In the Indian subcontinent, unsafe disposal of the stools of under-three children is more prevalent in Bangladesh (78\%), Nepal (69\%) and Afghanistan (52\%) [2, 4, 5], with India, not far behind. A recent study from rural Odisha reported that the stools of $90 \%$ of preambulatory and $70 \%$ of ambulatory children were disposed of unsafely [6]. Despite high levels of unsafe disposal, there is hardly any study that has examined the underlying socioeconomic and demographic determinants of unsafe disposal of children's stool in India.

Children's stools are a more dangerous source of faecal contamination in the household environment because children are more prone to be exposed to fecal pathogens 
than adults due to their behaviors [3, 7]. While crawling or playing, children may put contaminated fingers, pica or fomites into their mouth [8]. In India, children usually defecate in the compound or in and around the house on the ground and stools are usually left open [9]. Utensils, hands, and water can be easily contaminated by faecal pathogens and cause faecal-oral diseases [7]. Children are more susceptible to faecal-oral diseases, and thus, unsafe disposal of children's stool carries a higher health risk [10].

Diarrhea is the most common faecal-oral disease in children and is defined by the WHO as the passage of unusually loose or watery stool, usually at least three times in a twenty-four hour period [11]. Diarrhea is mostly infectious in nature [12]. Childhood diarrhea is the second leading cause of under-five mortality in the world. Estimates suggest that childhood diarrhea kills 760,000 children annually in the world [13]. Globally, diarrheal diseases contribute to $4 \%$ of the total disease burden, $3 \%$ of the overall mortality and $11 \%$ of the under-five mortality. In India, where the highest number of infant and child deaths occur, childhood diarrheal mortality is also the highest in the world [14-16]. Million Death Study Collaborators reported that diarrhea accounted for $26 \%$ of all under-five deaths (about 1.3 million) in India during 2001-03 [17].

Given the serious consequences of unsafe disposal of children's stools, a few epidemiological studies have reported the linkage of childhood diarrhea with the disposal of children's stools. Children whose stools are disposed of unsafely have a higher risk of diarrhea than those whose stools are disposed of safely, and the odds of diarrhea range from a minimum of 1.3 to a maximum of 2.2 [18-21]. In Sri Lanka, children from households where excreta was disposed of in a latrine were less likely to have diarrhea than children whose families disposed of excreta improperly [22]. A study from Iraq reported that children whose stools were put in a latrine/toilet were less likely to suffer from diarrhea than those whose stools were left in the open [23]. Indiscriminate disposal of stools was one of the risky behaviors of mothers causing diarrhea in children [24]. Studies from Ghana and India found that neighborhood sanitation and environment had a significant effect on child health and mortality $[25,26]$. Similarly, past studies have shown that children aged 6-23 months, male children and those born with low weight are at higher risk of diarrhea $[19,20$, $23,27-29]$. Use of unimproved toilet facilities and use of an unimproved source of drinking water increase children's susceptibility to diarrhea $[29,30]$. Besides, mother's illiteracy and lower age ( $<25$ years), the poor economic status of household and rural residence are also found to be associated with childhood diarrhea [19, 20, 28-31].

India is a large and diverse country where open defecation is very common and has highest under-five child deaths associated with diarrhea globally $[16,32]$.
However, to date, there is no national or state representative study that has investigated the effect of disposal of children's stools on childhood diarrhea. Perhaps, disposal of children's stools itself is an under-researched subject in India. Given the lack of systematic studies on the subject, our study aims to examine the magnitude of unsafe disposal of children's stools in India, the factors associated with it and the prevalence of diarrhea in children below five years of age. Finally, our study investigates the association between disposal of children's stool and childhood diarrhea after adjusting for selected socioeconomic and demographic factors. Also, we examine the association between diarrhea in children and unsafe disposal of children's stool in the neighborhood.

\section{Methods \\ Study design and setting}

The study is cross-sectional in nature and based on data from population-based National Family Health Survey 2005-06 (NFHS-3), India. NFHS-3 is a nationally representative population-based cross-sectional survey conducted across 29 states of India in 2005-06. The main objective of NFHS-3 was to provide national and state estimates of fertility, family planning, infant and child mortality, reproductive and child health, nutrition of women and children, and the quality of health and family welfare services. In India, NFHS-3 is the first survey that collected information on children's stool disposal practices.

NFHS-3 adopted a multistage sampling design - a two stage design in rural areas and a three stage design in urban areas for selecting households and eligible men and women for an interview. Altogether, 109,041 households, 124,385 women aged 15-49 years and 74,369 men aged 15-54 years were interviewed in the survey. The response rates were 98,94 , and $87 \%$, respectively $[33,34]$.

\section{Inclusion/exclusion criteria}

The information on diarrhea was collected for all children born during the five years preceding NFHS-3. The question related to disposal of stool was asked with respect to the youngest child born in the five years preceding NFHS-3. Hence, we included only the youngest child from each household in the analysis.

\section{Ethics statement}

The analysis presented in the paper is based on National Family Health Survey 2005-06 (NFHS-3) which is a publically available dataset with no identifiable information on the survey participants. All the ethical concerns, including informed consent, are strictly followed in the NFHS-3. Given these, no ethical approval or informed consent was required for the current study. 


\section{Variables}

To get details about the disposal of children's stools, mothers of under-five children were asked, "The last time (NAME OF YOUNGEST CHILD) passed stools, what was done to dispose of the stools"? The response categories to this questions included, 'child used the toilet or latrine,' 'put/rinsed into toilet or latrine,' 'put/ rinsed into drain/ditch,' 'thrown into the garbage,' 'buried,' 'left in the open,' and 'other.' Based on the WHO/ UNICEF definition, we generated a new variable, 'children's stool disposal' which has only two categories. The categories 'child used toilet or latrine, 'put/rinsed into toilet or latrine' and 'buried' were combined and coded as 'safe disposal of stool.' The others were coded as 'unsafe disposal of stool' [3]. Finally, the disposal of children's stools was coded as '0' if the stool was disposed of safely, and ' 1 ' otherwise.

To examine the factors associated with the disposal of children's stools, age and sex of children, mother's age, literacy (literate, illiterate) and working status of mother (currently working for cash/kind, not working), mother's exposure to media, religion and caste/tribe of household head, household's wealth, presence of improved toilet facility in the household and place of residence (urban, rural) were included in the analysis. The wealth index computed in NFHS-3 included 33 household assets including toilet facility and source of drinking water. Since we wanted to examine the independent effect of toilet facility and source of drinking water on the practice of stool disposal and prevalence of diarrhea, we generated a new wealth index which did not include toilet facility and source of drinking water. We followed the procedure of NFHS-3 to generate the new wealth index. The new wealth index was further categorized into lowest one-third (lowest), middle one-third (middle) and highest one-third (highest). The variable on media exposure includes exposure to newspaper, television, and radio. The mothers who were exposed to all the three media were coded as 'fully exposed.' Those who were exposed to one or two sources of media were coded as 'partially exposed.' The rest were coded as 'not exposed.' Further, the toilet facility and source of drinking water were categorized into 'improved' and 'unimproved' following the WHO/UNICEF definition [3].

For assessing the occurrence of diarrhea in children below five years of age, mothers were asked 'Has (NAME) had diarrhea in the last two weeks?' The diarrhea was coded as ' 0 ' if the mother reported 'no' and ' 1 ' otherwise. The key independent variable in the analysis of the occurrence of diarrhea is the disposal of children's stool. We also estimated a variable on unsafe disposal of children's stool in the neighborhood. This variable was estimated by taking the mean of unsafe disposal of children's stool over all children in a Primary Sampling Unit
(PSU) other than the index child. Age and sex of children, maternal age, literacy and working status of the mother, mother's exposure to media, religion and caste/ tribe of household head, household's wealth, the source of drinking water, toilet facility and birth size (larger, average, smaller) were also included in the analysis. In NFHS-3 mothers were asked to report the size of the baby at birth. The response categories were very large, larger than average, average, smaller than average and very small. The babies reported as 'very large' or 'larger than average' were coded as 'larger.' The babies reported as 'average' were coded as 'average' and those reported as 'smaller than average' and 'very small' were coded as 'smaller.' We also estimated a variable namely percentage of households in the neighborhood using unimproved toilet or practicing open defecation. This variable was estimated by taking the mean of the households using unimproved toilet or practicing open defecation over all households in a PSU other than the index household.

\section{Statistical analysis}

We used bivariate and multivariate analysis to fulfill the objectives of the paper. F-test was used in the bivariate analysis to examine the association between the dependent and the independent variables. We used a multivariable binary logistic regression model to examine the factors associated with unsafe disposal of children's stool and to examine the association between disposal of children's stools and the occurrence of diarrhea in children.

The analysis was carried out in STATA 13.0. Appropriate sampling weights were used in the estimations. We clustered standard errors at the PSU level to take into account the survey design of NFHS-3. All the independent variables were tested for possible multicollinearity before putting those into the regression models.

\section{Results}

Table 1 shows the percentage of unsafe disposal of children's stool by selected socioeconomic and demographic characteristics. Overall, the stool of nearly $79 \%$ of children was disposed of unsafely. The urban-rural gap in the unsafe disposal of stool was wide. The stools of nearly $88 \%$ of the children in rural areas were disposed of unsafely compared with $54 \%$ in urban areas. Strikingly, the disposal of stools of more than $50 \%$ of the children was unsafe even in urban India.

The results of the multivariable binary logistic regression assessing the factors associated with unsafe disposal of the stool are presented in Table 2. Lack of access to improved toilet facility was statistically associated with unsafe disposal of stool. The odds of disposing of stools unsafely among households having a lack of access to improved toilets were twice (AOR: 2.20; 95\% CI: 2.08-2.33) that of households having access to improved toilets. The 
Table 1 Unsafe disposal of children's stool by socioeconomic and demographic characteristics, India, 2005-06

\begin{tabular}{|c|c|c|c|c|c|}
\hline $\begin{array}{l}\text { Socioeconomic and } \\
\text { demographic characteristics }\end{array}$ & Unsafe (\%) & $P$-value & Number & $\begin{array}{l}\text { Socioeconomic and } \\
\text { demographic characteristics }\end{array}$ & $\begin{array}{l}\text { Adjusted Odds Ratio } \\
(95 \% \mathrm{Cl})\end{array}$ \\
\hline Toilet facility & & & & Toilet facility & \\
\hline Improved & 53.8 & 0.000 & 11,909 & Improved $^{\oplus}$ & \\
\hline Unimproved & 86.8 & & 23,364 & Unimproved & $2.20 *(2.08,2.33)$ \\
\hline Age of mother (in years) & & & & Age of mother (in year) & \\
\hline $20-34$ & 76.6 & 0.000 & 27,663 & $20-34^{\oplus}$ & \\
\hline $15-19$ and $35-49$ & 86.0 & & 7610 & $15-19$ and $35-49$ & $1.06(0.99,113)$ \\
\hline Mother's literacy & & & & Mother's literacy & \\
\hline Non-Literate & 91.2 & & 13,368 & Non-literate ${ }^{\oplus}$ & \\
\hline Literate & 67.7 & 0.000 & 21,905 & Literate & $0.57^{*}(0.53,0.61)$ \\
\hline Mother's working status & & & & Mother's working status & \\
\hline Not working & 76.0 & 0.000 & 24,894 & Not working ${ }^{\circledast}$ & \\
\hline Working & 85.2 & & 10,379 & Working & $0.99(0.93,1.06)$ \\
\hline Mother's exposure to media & & & & Mother's exposure to media & \\
\hline No & 92.5 & 0.000 & 8023 & $\mathrm{No}^{\oplus}$ & \\
\hline Partial & 86.4 & & 9265 & Partial & $0.82^{*}(0.75,0.91)$ \\
\hline Full & 63.7 & & 17,985 & Full & $0.63^{*}(0.57,0.70)$ \\
\hline Age of child (in months) & & & & Age of child (in months) & \\
\hline $0-5$ & 88.0 & 0.000 & 4619 & $0-5^{\oplus}$ & \\
\hline $6-11$ & 87.0 & & 4859 & $6-11$ & $3.51 *(3.20,3.85)$ \\
\hline $12-17$ & 85.2 & & 4733 & $12-17$ & $3.19^{*}(2.92,3.48)$ \\
\hline $18-59$ & 73.3 & & 21,062 & $18-59$ & $2.49 *(2.29,2.72)$ \\
\hline Sex of child & & & & Sex of child & \\
\hline Male & 78.0 & 0.003 & 18,921 & Male $^{\circledast}$ & \\
\hline Female & 80.0 & & 16,352 & Female & $1.00(0.95,1.05)$ \\
\hline Religion & & & & Religion & \\
\hline Hindu & 80.7 & 0.000 & 24,683 & $\mathrm{Hindu}^{\oplus}$ & \\
\hline Muslim & 74.5 & & 5,610 & Muslim & $0.69 *(0.64,0.75)$ \\
\hline Other religion & 61.0 & & 4,980 & Other religion & $0.44^{*}(0.40,0.48)$ \\
\hline Caste/Tribe & & & & Caste/Tribe & \\
\hline Scheduled Caste (SC) & 86.8 & 0.000 & 6056 & Scheduled Caste (SC) ${ }^{\oplus}$ & \\
\hline Scheduled Tribe (ST) & 89.7 & & 5463 & Scheduled Tribe (ST) & $1.45^{*}(1.34,1.57)$ \\
\hline Non SC/ST & 75.1 & & 23,754 & Non SC/ST & $0.97(0.88,1.07)$ \\
\hline Wealth index & & & & Wealth index & \\
\hline Lowest & 94.0 & 0.000 & 13,918 & Lowest $^{\oplus}$ & \\
\hline Middle & 78.0 & & 11,553 & Middle & $0.50^{*}(0.46,0.54)$ \\
\hline Highest & 44.7 & & 9802 & Highest & $0.23^{*}(0.21,0.26)$ \\
\hline Place of residence & & & & Place of residence & \\
\hline Urban & 52.6 & 0.000 & 14,012 & Urban $^{\circledast}$ & \\
\hline Rural & 88.5 & & 21,261 & Rural & $2.42 *(2.28,2.57)$ \\
\hline
\end{tabular}

Total

All values in the table represent absolute numbers and percentages unless otherwise stated

Percentages are weighted and Ns are unweighted
Table 2 Results of multivariable binary logistic regression showing the risk of unsafe stool disposal, India, 2005-06

odds of disposing of the stools unsafely were $43 \%$ lower (AOR: 0.57; 95\% CI: 0.53-0.61) in literate mothers than illiterate mothers. Unsafe disposal of stool also depended 
on the mother's exposure to media. The odds of unsafe stool disposal was 37\% lower (AOR: 0.63; 95\% CI: 0.570.70 ) in mothers who were fully exposed to media than in mothers who were not exposed to media. Similarly, the odds of disposing of the stools unsafely were $18 \%$ lower (AOR: 0.82; 95\% CI: 0.75-0.91) in mothers who were partially exposed to media than those who were not exposed to media. Age of the mother and mother's work were not associated with unsafe disposal of stool in the regression model.

Unsafe disposal of stool was also statistically associated with the religion of the head of the household. The odds of unsafe disposal were $31 \%$ lower (AOR: 0.69 ; $95 \% \mathrm{CI}$ : 0.64-0.75) among Muslim households than Hindu households. Likewise, the odds of disposing of stools unsafely among households from 'Other religion' were 56\% lower (AOR: 0.44; 95\% CI: 0.40-0.48) than Hindu households. Another variable that was statistically associated with unsafe disposal of stool was the household's wealth index. The odds of unsafe disposal among middle one-third households was half (AOR: 0.50; 95\% CI: 0.46-0.54) that of the lowest one-third households. Likewise, the odds of disposing of stools unsafely was $77 \%$ lower (AOR: 0.23; 95\% CI: 0.21-0.26) in highest onethird households than in lowest one-third households. The odds of unsafe disposal among households residing in rural areas were twice (AOR: 2.42; 95\% CI: 2.28-2.57) compared to households residing in urban areas.

Table 3 presents the prevalence of diarrhea in children below five years of age by selected socioeconomic and demographic characteristics. Overall, $11 \%$ of children below five years of age suffered from diarrhea. The prevalence of diarrhea did not vary by urban-rural residence. Age of mother, mother's exposure to media, the age of child, sex of child, size of the child at birth, religion, and wealth index were statistically associated with the prevalence of diarrhea in the bivariate analysis.

We estimate three separate multivariable binary logistic regression models to examine the association between unsafe disposal of children's stool and diarrhea in children (Table 4). The first model included disposal of children's stool, the source of drinking water, children and mother related and household related characteristics. The results indicate a statistically significant association between unsafe disposal of children's stool and diarrhea in children. The odds of suffering from diarrhea was $11 \%$ higher (AOR: 1.11; 95\% CI: 1.01-1.21) in children whose stools were disposed of unsafely compared to children whose stools were disposed of safely. The results adjusted for stool disposal of neighborhood children (Model 2) indicate a statistically significant association between unsafe disposal of children's stool in the neighborhood and diarrhea in children. A unit increase in the proportion of unsafe disposal of children's stool in the
Table 3 Prevalence of diarrhea in children below 5 years of age by socioeconomic and demographic characteristics, India, 2005-06

\begin{tabular}{|c|c|c|c|c|}
\hline \multicolumn{2}{|c|}{$\begin{array}{l}\text { Socioeconomic and } \\
\text { demographic characteristics }\end{array}$} & \multirow{2}{*}{$\begin{array}{c}\text { Prevalence (\%) } \\
9.0\end{array}$} & \multirow{2}{*}{$\begin{array}{l}P \text {-value } \\
0.000\end{array}$} & \multirow{2}{*}{$\begin{array}{l}\text { Number } \\
11,202\end{array}$} \\
\hline Children's stool & Safe & & & \\
\hline & Unsafe & 11.2 & & 24,067 \\
\hline \multirow[t]{2}{*}{ Toilet facility } & Improved & 9.6 & 0.008 & 11,907 \\
\hline & Unimproved & 11.0 & & 23,362 \\
\hline \multirow{2}{*}{$\begin{array}{l}\text { Source of drinking } \\
\text { water }\end{array}$} & Improved & 10.6 & 0.321 & 27,287 \\
\hline & Unimproved & 11.1 & & 7981 \\
\hline \multirow{4}{*}{$\begin{array}{l}\text { Age of child } \\
\text { (in months) }\end{array}$} & $0-5$ & 10.5 & 0.000 & 21,058 \\
\hline & $6-11$ & 18.1 & & 4619 \\
\hline & $12-17$ & 15.7 & & 4859 \\
\hline & $18-59$ & 7.9 & & 4733 \\
\hline \multirow[t]{2}{*}{ Sex of child } & Male & 11.1 & 0.045 & 18,919 \\
\hline & Female & 10.3 & & 16,350 \\
\hline \multirow{3}{*}{$\begin{array}{l}\text { Size of child at } \\
\text { birth }\end{array}$} & Larger & 10.5 & 0.000 & 8104 \\
\hline & Average & 9.8 & & 19,576 \\
\hline & Smaller & 13.1 & & 7588 \\
\hline \multirow{2}{*}{$\begin{array}{l}\text { Age of mother } \\
\text { (in years) }\end{array}$} & $20-34$ & 10.4 & 0.005 & 27,659 \\
\hline & $15-19$ and 35-49 & 11.8 & & 7610 \\
\hline \multirow[t]{2}{*}{ Mother's literacy } & Non-literate & 10.9 & 0.357 & 21,902 \\
\hline & Literate & 10.5 & & 13,367 \\
\hline \multirow{2}{*}{$\begin{array}{l}\text { Mother's working } \\
\text { status }\end{array}$} & Not working & 11.1 & 0.005 & 24,890 \\
\hline & Working & 9.8 & & 10,379 \\
\hline \multirow{3}{*}{$\begin{array}{l}\text { Mother's exposure } \\
\text { to media }\end{array}$} & No & 11.0 & 0.190 & 8023 \\
\hline & Partial & 11.1 & & 9265 \\
\hline & Full & 10.2 & & 17,981 \\
\hline \multirow[t]{3}{*}{ Religion } & Hindu & 10.4 & 0.043 & 24,681 \\
\hline & Muslim & 12.0 & & 5608 \\
\hline & Other religion & 11.1 & & 4980 \\
\hline \multirow[t]{3}{*}{ Caste/Tribe } & SC & 10.7 & 0.946 & 6056 \\
\hline & $\mathrm{ST}$ & 10.9 & & 5463 \\
\hline & Non SC/ST & 10.7 & & 23,750 \\
\hline \multirow[t]{3}{*}{ Wealth index } & Lowest & 11.0 & 0.058 & 13,918 \\
\hline & Middle & 11.0 & & 11,551 \\
\hline & Highest & 9.7 & & 9800 \\
\hline \multirow[t]{2}{*}{ Place of residence } & Urban & 10.3 & 0.258 & 14,009 \\
\hline & Rural & 10.9 & & 21,260 \\
\hline \multicolumn{2}{|l|}{ Total } & 10.7 & & 35,269 \\
\hline
\end{tabular}

All values in the table represent absolute numbers and percentages unless otherwise stated. Percentages are weighted and Ns are unweighted

neighborhood was associated with a $1 \%$ higher risk of diarrhea in children (AOR: 1.01; 95\% CI: 1.00-1.01). The effect of unsafe disposal of children's stool was lost the moment we included the variable on unsafe disposal of children's stool in the neighborhood in the regression 
Table 4 Results of multivariable binary logistic regression showing the risk of diarrhea in children below 5 years of age, India, 2005-06

\begin{tabular}{|c|c|c|c|c|}
\hline \multicolumn{2}{|c|}{ Socioeconomic and demographic characteristics } & \multicolumn{3}{|c|}{ Adjusted Odds Ratio (95\% Cl) } \\
\hline & & Model 1 & Model 2 & Model 3 \\
\hline \multirow[t]{2}{*}{ Children's stool disposal } & $\mathrm{Safe}^{\circledast}$ & & & \\
\hline & Unsafe & $1.11^{*}(1.01,1.21)$ & $1.04(0.94,1.14)$ & $1.02(0.93,1.12)$ \\
\hline \multicolumn{2}{|l|}{$\begin{array}{l}\text { Unsafe disposal of children's stool in the } \\
\text { neighborhood (\%) }\end{array}$} & - & $1.01 *(1.00,1.01)$ & $1.01 *(1.00,1.01)$ \\
\hline \multicolumn{2}{|l|}{$\begin{array}{l}\text { Percentage of households in the } \\
\text { neighborhood using unimproved toilet } \\
\text { or practicing open defecation }\end{array}$} & - & - & $1.00 *(0.99,1.01)$ \\
\hline \multirow[t]{2}{*}{ Toilet facility } & Improved ${ }^{\otimes}$ & - & - & \\
\hline & Unimproved & - & - & $0.99(0.89,1.09)$ \\
\hline \multirow[t]{2}{*}{ Source of drinking water } & Improved ${ }^{\otimes}$ & & & \\
\hline & Unimproved & $0.99(0.91,1.07)$ & $0.98(0.90,1.06)$ & $0.98(0.90,1.06)$ \\
\hline \multirow[t]{4}{*}{ Age of child (in months) } & $0-5^{\oplus}$ & & & \\
\hline & $6-11$ & $1.84^{*}(1.64,2.08)$ & $1.85^{*}(1.64,2.08)$ & $1.84^{*}(1.64,2.08)$ \\
\hline & $12-17$ & $1.52^{*}(1.34,1.72)$ & $1.52 *(1.34,1.72)$ & $1.52^{*}(1.34,1.72)$ \\
\hline & $18-59$ & $0.77^{*}(0.69,0.86)$ & $0.77^{*}(0.69,0.85)$ & $0.77^{*}(0.69,0.85)$ \\
\hline \multirow[t]{2}{*}{ Sex of child } & Male ${ }^{\circledast}$ & & & \\
\hline & Female & $0.90^{*}(0.84,0.96)$ & $0.90^{*}(0.84,0.96)$ & $0.90 *(0.84,0.96)$ \\
\hline \multirow[t]{3}{*}{ Size of child at birth } & Large & & & \\
\hline & Average & $0.88^{*}(0.81,0.96)$ & $0.87^{*}(0.80,0.95)$ & $0.88^{*}(0.80,0.95)$ \\
\hline & Small & $1.24^{*}(1.13,1.37)$ & $1.24^{*}(1.13,1.37)$ & $1.24^{*}(1.13,1.37)$ \\
\hline \multirow[t]{2}{*}{ Age of mother (in year) } & $20-34^{\oplus}$ & & & \\
\hline & $15-19$ and $35-49$ & $1.02(0.94,1.10)$ & $1.01(0.93,1.10)$ & $1.01(0.93,1.10)$ \\
\hline \multirow[t]{2}{*}{ Mother's literacy } & Non-literate ${ }^{\oplus}$ & & & \\
\hline & Literate & $1.10^{*}(1.01,1.20)$ & $1.13^{*}(1.04,1.23)$ & $1.14^{*}(1.05,1.24)$ \\
\hline \multirow[t]{2}{*}{ Mother's working status } & Not working ${ }^{\oplus}$ & & & \\
\hline & Working & $1.01(0.93,1.09)$ & $1.01(0.93,1.09)$ & $1.01(0.93,1.09)$ \\
\hline \multirow[t]{3}{*}{ Mother's exposure to media } & $\mathrm{No}^{\oplus}$ & & & \\
\hline & Partial & $1.06(0.96,1.18)$ & $1.07(0.97,1.18)$ & $1.07(0.97,1.19)$ \\
\hline & Full & $1.01(0.90,1.12)$ & $1.03(0.92,1.15)$ & $1.03(0.92,1.15)$ \\
\hline \multirow[t]{3}{*}{ Religion } & $H_{i n d u}{ }^{\oplus}$ & & & \\
\hline & Muslim & $1.14^{*}(1.03,1.25)$ & $1.12 *(1.01,1.23)$ & $1.13^{*}(1.03,1.24)$ \\
\hline & Other religion & $1.03(0.92,1.16)$ & $1.05(0.93,1.17)$ & $1.08(0.96,1.21)$ \\
\hline \multirow[t]{3}{*}{ Caste/Tribe } & $\mathrm{SC}^{\oplus}$ & & & \\
\hline & ST & $0.93(0.82,1.07)$ & $0.93(0.82,1.06)$ & $0.94(0.82,1.07)$ \\
\hline & Non SC/ST & $0.96(0.88,1.06)$ & $0.96(0.87,1.06)$ & $0.96(0.88,1.06)$ \\
\hline \multirow[t]{3}{*}{ Wealth index } & Lowest $^{\oplus}$ & & & \\
\hline & Middle & $0.97(0.88,1.06)$ & $1.00(0.91,1.10)$ & $1.00(0.91,1.10)$ \\
\hline & Highest & $0.89(0.79,1.00)$ & $0.92(0.82,1.04)$ & $0.95(0.84,1.07)$ \\
\hline \multirow[t]{2}{*}{ Place of residence } & Urban $^{\oplus}$ & & & \\
\hline & Rural & $0.97(0.90,1.06)$ & $0.92(0.84,1.00)$ & $0.90^{*}(0.83,0.99)$ \\
\hline
\end{tabular}

Cl confidence interval; ${ }^{*} p$-value $<0.05$

model. We also included the use of toilet facility and proportion of households using the unimproved toilet or practicing open defecation in the neighborhood in Model 3.
Unsafe disposal of children's stool in the neighborhood was statistically associated with higher risk of diarrhea in children. This finding clearly indicates that the unsafe disposal 
of children's stool in the neighborhood has a much larger association with diarrhea than the unsafe disposal of index child's stool. The other variables that were associated with diarrhea in children in multivariable binary logistic regression analysis are the age of the child, sex of the child, the size of the child at birth, mother's literacy and proportion of households using the unimproved toilet in the community.

\section{Discussion}

Our study is perhaps the first in India that has examined the socioeconomic and demographic determinants of unsafe disposal of children's stools. It is also the first study in India that uses a large-scale population-based representative dataset to investigate the association between unsafe disposal of stool and diarrhea in children. Overall, the stool of $79 \%$ of children below five years of age was disposed of unsafely. Being non-literate, having lower exposure to media, belonging to Hindu religion, belonging to scheduled castes/tribes, having lower wealth quintile, having access to unimproved toilet facility and being a rural resident were the factors associated with unsafe disposal of children's stool. A study in Burkina Faso also suggested a significant association of wealth and education with hygienic behavior [35]. Curtis et al. (2001) suggested that health promotion programmes, through health education and mass media, resulted in $4 \%$ increase in safe disposal of stool in Burkina Faso [36]. A study conducted in Ethiopia also reported similar findings [37]. Our findings are also consistent with the findings of a recent study conducted in rural Odisha [6].

Our study confirms the association between disposal of children's stools and diarrhea in children below five years of age. Children whose stools were disposed of unsafely were more likely to suffer from diarrhea than children whose stools were disposed of safely. A few studies conducted in different settings support our findings [18-21]. We further found that children were more likely to have diarrhea if stool of children residing in the neighborhood was disposed of unsafely. This finding is also consistent with the studies from Ghana and India, where household externalities played an important role in child health and mortality $[25,26]$. The other variables that were associated with diarrhea in children in multivariable binary logistic regression analysis are the age of the child, sex of the child, the size of the child at birth and mother's literacy. Studies conducted in Sub-Saharan Africa, Iraq, and Turkey support our findings [20,23, 28, 29,38].

Our findings have important policy implications. A key finding of our study is that increased access to improved toilets is likely to reduce the unsafe disposal of stool in India. In this context, our study lends support to the 'Swachh Bharat Mission,' which emphasizes making available basic sanitation facilities to all Indians by 2019 [39]. The mission aims to build 66575 household latrines per day to cover all households in five years. However, our findings show that even in households that have access to improved toilets, the disposal of stools of $54 \%$ percent of the children is unsafe. This indicates that just having access to improved toilets does not ensure utilization of the toilet facility for disposing of the children's stool. Moreover, in nearly 33\% of rich households, stools of $45 \%$ of the children were disposed of unsafely. Also, the effective disposal of child feces is an essential indicator for open defecation free certification under the Swachh Bharat Mission. A document prepared by the World Sanitation Programme reports that despite a few interventions, there is still not a strong evidence base of effective strategies for reducing the unsafe disposal of child feces [40]. Our findings call for strategies that go beyond building toilets. Strategies such as motivating and educating mothers on safe disposal of children's stools along with building toilets can go a long way in curbing the unsafe disposal of children's stools in India. Mothers who do not have access to improved toilet facility must be informed on the safe burial of children's stools.

Our findings show that increase in maternal education and media exposure are likely to reduce the unsafe disposal of children's stools. These findings indicate that health promotional activities must make active use of Information Education and Communication (IEC) and mass media. Village Health, Sanitation, and Nutrition Committees (VHSNC) set up under the National Rural Health Mission (NRHM) need to be strengthened, trained and made functional for creating awareness among communities about the safe disposal of stools. Community health workers like Accredited Social Health Activists (ASHA) and Anganwadi Workers (AWW) may be engaged to educate women on safe disposal of stools.

\section{Strengths and limitations of study}

The strengths and limitations of the study must be noted. One of the major strengths is the use of a nationally representative population-based dataset for examining the method of disposal of children's stools and its effect on diarrhea in the Indian context. In fact, NFHS-3 is the first and only large-scale survey in India, which collected information on practices regarding disposal of stools.

A key limitation of the study is that the data used in the analysis dates back to 2005-06. The Government of India has built latrines under various programs over this period [39]. However, we would like to mention that NFHS-3 is the most recent large-scale household survey that has collected information on children's stool disposal and prevalence of diarrhea in India. Also, the NFHS-3 reported that $29 \%$ of the households in India 
had access to improved toilet in 2005-06 [33]. The latest Indian Census (conducted in India in 2011) shows that about $30 \%$ of the households in India have access to improved toilet [41]. These data, thus, suggest that there is not much difference in the access to improved toilet in NFHS-3 and recent estimates obtained from the Indian Census. Moreover, the underestimation of access to improved toilet, if at all present in NFHS-3, should not affect the relationship between children's stool disposal and occurrence of diarrhea in India as studies have shown that access to improved toilet is not a guarantee that the children's stool will be disposed of safely $[42,43]$. Another limitation of the study is that we could not adjust the results for the effect of washing hands on diarrhea because the information on washing hands was not collected in NFHS-3. We also could not adjust the odds ratio for birth weight in the diarrhea analysis. However, we did adjust the odds ratio for the size of the baby at birth. In settings where birth weight is not available for all children, the size of children at birth is a good proxy for birth weight. According to the NFHS-3, about $66 \%$ of the children below five years of age were not weighed at birth [33]. Another limitation of our study relates to the way in which information on disposal of stools was collected in NFHS-3. The NFHS-3 relied on reported practice rather than direct observation. While Gil et al. (2004) found greater precision in studies employing structured observations [44], Clasen et al. (2012) found that direct observations are subject to reactivity (Hawthorne effect) in the study population [43]. Reporting bias and recall lapse in our study is likely to be least because the NFHS-3 enquired about the 'last time' rather than the usual practice of disposal of stools. Again, the measurement of the prevalence of diarrhea in NFHS-3 is based on a 14-day recall period. Manesh et al. (2008) reported significant recall and reporting bias in childhood morbidities in Demographic and Health Surveys (DHS) [45]. Similarly, Schmidt et al. (2011) argued that DHSs should collect point prevalence rather than the period prevalence of diarrhea [46]. However, all the DHSs conducted in India and abroad and the UNICEF sponsored surveys in India use a 14-day recall period to measure the prevalence of diarrhea in children.

\section{Conclusion}

Despite these limitations, this study brings to the forefront the magnitude of unsafe disposal of children's stools in India. This study also provides empirical evidence on the association between unsafe disposal of children's stool in a community and diarrhea in children. Our study raises a number of questions about the effectiveness of the sanitation programmes being run in India. Given the serious consequences of unsafe disposal of children's stool, there is a need to redesign the sanitation programmes being run in India. Children remain vulnerable to diarrhea till the stools of all children in the neighborhood are not disposed of safely. Thus, inclusion of strategies to reduce unsafe disposal of children's stools in the sanitation programmes can go a long way in reducing the risk of diarrhea in children below five years of age.

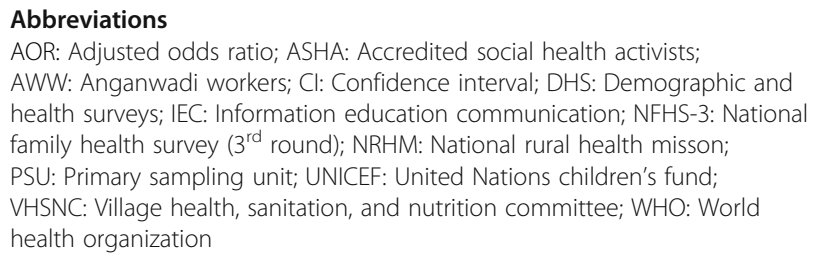

\section{Acknowledgements}

Authors sincerely acknowledge the three reviewers whose comments helped immensely in improving the quality of the paper.

\section{Funding}

Not received.

\section{Availability of data and materials}

All data and material are available within the paper.

\section{Authors' contributions}

RB conceived the idea, designed the experiment and analyzed the data. AS supervised the data analysis and contributed to writing and editing the first draft of the paper. KK helped in data analysis and commented on the first draft. SP commented on the first and subsequent drafts and did the final editing. All authors read and approved the final manuscript.

\section{Competing interests}

The authors declare that they have no competing interests.

\section{Consent for publication}

Not applicable.

Ethics approval and consent to participate

Not applicable.

\section{Author details}

${ }^{1}$ International Institute for Population Sciences, Mumbai, India. ${ }^{2}$ Department of Public Health \& Mortality Studies, International Institute for Population Sciences, Mumbai, India. ${ }^{3}$ Department of Population Policies and Programmes, International Institute for Population Sciences, Mumbai, India.

Received: 17 February 2016 Accepted: 15 December 2016 Published online: 05 January 2017

\section{References}

1. Brown J, Cairncross S, Ensink JH. Water, sanitation, hygiene and enteric infections in children. Arch Dis Child. 2013;98(8):629-34.

2. WSP, UNICEF. Part 1 of 2: Child Feces Disposal in Bangladesh: World Sanitation Program; 2014. p. 1-4. Available at: http://www.wsp.org/sites/ wsp.org/files/publications/WSP-Child-Feces-Disposal-Bangladesh-Part1.pdf. Accessed 20 Apr 2015

3. WHO, UNICEF: Core Questions on Drinking-Water and Sanitation for Household Surveys. Geneva: World Health Organisation and UNICEF; 2006. Available at http://www.who.int/water_sanitation_health/monitoring/oms brochure core questionsfinal24608.pdf. Accessed 30 Jan 2015.

4. WSP, UNICEF. Child Feces Disposal in NEPAL: The World Bank and UNICEF 2015. p. 1-4. Available at http://unicef.org.np/uploads/files/

147283966787844156-nepal-cfd-final-dec-2014.pdf. Accessed 20 Apr 2015.

5. WSP, UNICEF: Child feces Disposal in Afganistan: International Bank for Reconstruction and Development/The World Bank and UNICEF; 2015: 1-4. 
Available at https:/www.wsp.org/sites/wsp.org/files/publications/WSPAfghanistan-CFD-Profile.pdf. Accessed 20 Apr 2015.

6. Majorin F, Freeman MC, Barnard S, Routray P, Boisson S, Clasen T. Child feces disposal practices in rural Orissa: a cross sectional study. PLoS One. 2014;9(2):e89551.

7. $\mathrm{WHO}$. Improving water and sanitation hygiene behaviors for the reduction of diarrheal disease - The report of an informal consultation, Geneva, 18-20 May 1992. Geneva: Community Water Supply and Sanitation Unit (CWS), Control for Diarrheal Disease Program (CDD), World Health Organization, Geneva; 1993.

8. Moya J, Bearer CF, Etzel RA. Children's behavior and physiology and how it affects exposure to environmental contaminants. Pediatrics. 2004;113(4 Suppl):996-1006.

9. Lanata CF, Huttly SR, Yeager BA. Diarrhea: whose feces matter? Reflections from studies in a Peruvian shanty town. Pediatr Infect Dis J. 1998;17(1):7-9.

10. Fischer Walker CL, Perin J, Aryee MJ, Boschi-Pinto C, Black RE. Diarrhea incidence in low- and middle-income countries in 1990 and 2010: a systematic review. BMC Public Health. 2012;12:220.

11. WHO. The Treatment of diarrhoea : a manual for physicians and other senior health workers. 4th ed. Geneva: World Health Organization 2005; 2005.

12. Annette Prüss-Üstün RB, Fiona $\mathrm{G}$, Jamie B. Safer water, better health: costs, benefits and sustainability of interventions to protect and promote health. Geneva: World Health Organization; 2008

13. Black RE, Cousens S, Johnson HL, Lawn JE, Rudan I, Bassani DG, Jha P, Campbell H, Walker CF, Cibulskis R, et al. Global, regional, and national causes of child mortality in 2008: a systematic analysis. Lancet. 2010; 375(9730):1969-87.

14. Lopez AD, Mathers CD, Ezzati M, Jamison DT, Murray CJ. Global and regional burden of disease and risk factors, 2001: systematic analysis of population health data. Lancet. 2006;367(9524):1747-57.

15. UNICEF, WHO. Diarrhoea: Why children are still dying and what can be done. New York: The United Nations Children's Fund (UNICEF) and World Health Organization (WHO); 2009. Available at http://www.unicef.org/media/files/ Final_Diarrhoea_Report_October_2009_final.pdf. Accessed 20 May 2015.

16. Liu L, Johnson HL, Cousens S, Perin J, Scott S, Lawn JE, Rudan I, Campbell H, Cibulskis R, Li M, et al. Global, regional, and national causes of child mortality: an updated systematic analysis for 2010 with time trends since 2000. Lancet. 2012:379(9832):2151-61.

17. Million Death Study C, Bassani DG, Kumar R, Awasthi S, Morris SK, Paul VK, Shet A, Ram U, Gaffey MF, Black RE, et al. Causes of neonatal and child mortality in India: a nationally representative mortality survey. Lancet. 2010; 376(9755):1853-60.

18. Tilahun Belete Mossie DGT, Addisu Workineh Kassa. Childhood diarrheal disease among under five children at Dejen district, Northwest Ethiopia. Am J Health Res. 2014;2(4):177-81.

19. Sinmegn Mihrete T, Asres Alemie G, Shimeka Teferra A. Determinants of childhood diarrhea among underfive children in Benishangul Gumuz Regional State, North West Ethiopia. BMC Pediatr. 2014;14(1):102.

20. Bezatu Mengistie YB, Worku A. Prevalence of diarrhea and associated risk factors among children under-five years of age in Eastern Ethiopia: a crosssectional study. Open J Prev Med. 2013;3:446-53.

21. Traore E, Cousens S, Curtis V, Mertens T, Tall F, Traore A, Kanki B, Diallo I, Rochereau A, Chiron JP, et al. Child defecation behaviour, stool disposal practices, and childhood diarrhoea in Burkina Faso: results from a casecontrol study. J Epidemiol Community Health. 1994;48(3):270-5.

22. Mertens TE, Jaffar S, Fernando MA, Cousens SN, Feachem RG. Excreta disposal behaviour and latrine ownership in relation to the risk of childhood diarrhoea in Sri Lanka. Int J Epidemiol. 1992;21(6):1157-64.

23. Siziya S, Muula AS, Rudatsikira E. Diarrhoea and acute respiratory infections prevalence and risk factors among under-five children in Iraq in 2000. Ital J Pediatr. 2009:35(1):8

24. Ghosh S, Sengupta P, Mondal S, Banu M, Gupta D, Sircar B. Risk behavioural practices of rural mothers as determinants of childhood diarrhoea. J Commun Dis. 1997;29(1):7-14.

25. Fobil JN, Kraemer A, Meyer CG, May J. Neighborhood urban environmental quality conditions are likely to drive malaria and diarrhea mortality in Accra, Ghana. J Environ Public Health. 2011;2011:484010.

26. Geruso M, Spears D. Neighborhood sanitation and infant mortality. In: National bureau of economic research. 2015.

27. Yassin K. Morbidity and risk factors of diarrheal diseases among under-five children in rural upper Egypt. J Trop Pediatr. 2000;46(5):282-7.
28. Siziya S, Muula AS, Rudatsikira E. Correlates of diarrhoea among children below the age of 5 years in Sudan. Afr Health Sci. 2013;13(2):376-83.

29. Etiler N, Velipasaoglu S, Aktekin M. Risk factors for overall and persistent diarrhoea in infancy in Antalya, Turkey: a cohort study. Public Health. 2004;1 18(1):62-9.

30. Diouf K, Tabatabai P, Rudolph J, Marx M. Diarrhoea prevalence in children under five years of age in rural Burundi: an assessment of social and behavioural factors at the household level. Glob Health Action. 2014;7:24895.

31. Avachat SS, Phalke VD, Phalke DB, Aarif SMM, Kalakoti P. A cross-sectional study of socio-demographic determinants of recurrent diarrhoea among children under five of rural area of Western Maharashtra, India. Australas Med J. 2011;4(2):72-5.

32. UNICEF, WHO. Progress on sanitation and drinking water - 2015 update and MDG assessment. Geneva: WHO; 2015. p. 1-90.

33. International Institute for Population Sciences (IIPS), Macro International. National Family Health Survey (NFHS-3) (Vol 1), 2005-06, India. Mumbai: IIPS, Mumbai; 2007.

34. International Institute for Population Sciences (IIPS), Macro International. National Family Health Survey (NFHS-3) (Vol 2), 2005-06, India, vol. 2. Mumbai: IIPS Mumbai; 2007.

35. Curtis V, Kanki B, Mertens T, Traore E, Diallo I, Tall F, Cousens S. Potties, pits and pipes: explaining hygiene behaviour in Burkina Faso. Soc Sci Med. 1995; 41(3):383-93.

36. Curtis V, Kanki B, Cousens S, Diallo I, Kpozehouen A, Sangare M, Nikiema M. Evidence of behaviour change following a hygiene promotion programme in Burkina Faso. Bull World Health Organ. 2001;79(6):518-27.

37. Azage $M$, Haile D. Factors associated with safe child feces disposal practices in Ethiopia: evidence from demographic and health survey. Arch Public Health. 2015;73:40.

38. Mashoto KO, Malebo HM, Msisiri E, Peter E. Prevalence, one week incidence and knowledge on causes of diarrhea: household survey of under-fives and adults in Mkuranga district, Tanzania. BMC Public Health. 2014:14:985.

39. Government of India MoUD. Swachh Bharat Mission; 2015. Available at http://www.swachhbharaturban.in/sbm/home/\#/SBM. Accessed 21 May 2015.

40. WSP, UNICEF. Child Feces Disposal in India: International Bank for Reconstruction and Development/The World Bank and UNICEF; 2015. p. 14. Available athttps://www.wsp.org/sites/wsp.org/files/publications/WSPIndia-CFD-Profile.pdf. Accessed 20 Apr 2015.

41. Registrar General of India. Housing micro data sample: census of India 2011. New Delhi: Office of the Registrar General of India; 2011.

42. Patil SR, Arnold BF, Salvatore AL, Briceno B, Ganguly S, Colford Jr JM, Gertler PJ. The effect of India's total sanitation campaign on defecation behaviors and child health in rural Madhya Pradesh: a cluster randomized controlled trial. PLoS Med. 2014;11(8):e1001709.

43. Clasen T, Boisson S, Routray P, Torondel B, Bell M, Cumming O, Ensink J, Freeman $\mathrm{M}$, Jenkins $\mathrm{M}$, Odagiri $\mathrm{M}$, et al. Effectiveness of a rural sanitation programme on diarrhoea, soil-transmitted helminth infection, and child malnutrition in Odisha, India: a cluster-randomised trial. Lancet Global Health. 2014;2(11):e645-53.

44. Ana Gil CL, Kleinau E, Penny M. Children's feces disposal practices in developing countries and interventions to prevent diarrheal diseases a literature review. Washington: Environmental Health Project, USAID; 2004.

45. Manesh AO, Sheldon TA, Pickett KE, Carr-Hill R. Accuracy of child morbidity data in demographic and health surveys. Int J Epidemiol. 2008;37(1):194-200.

46. Schmidt WP, Arnold BF, Boisson S, Genser B, Luby SP, Barreto ML, Clasen T, Cairncross S. Epidemiological methods in diarrhoea studies-an update. Int J Epidemiol. 2011;40(6):1678-92. 